\title{
Conversation Analysis in Courtroom Discourse
}

\author{
Dan Zhang ${ }^{1}$ \\ College of Foreign Language, Henan University of Science and Technology, Luoyang, \\ Henan, China \\ Email:jerryzhangdan070@sina.com
}

Keywords: Conversation Analysis; Courtroom Discourse; Implicature; Maxim;

\begin{abstract}
From the perspective of qualitative study, the author analyzes the implicature in the courtroom discourse. During the courtroom interaction, different participants will employ conversational implicature to achieve his/her purpose, violating cooperative principle is the important tool of generating conversational implicature. Moreover, for the lawyer, the function of implicature is to undermine the creditability of the testimony. While, for the defendant, he/she will prove his/her innocent and the real testimony that he/she provided.
\end{abstract}

\section{Studies on Conversation Analysis}

Conversation analysis is the approach to the study of the social interaction, including both verbal and non-verbal conduct, in situations of everyday life. It is a kind of established method which has been used in different fields, such as sociology, anthropology, linguistics and psychology. Grice has proposed four conversational maxims. It is the way to explain the link between utterances and what is understood from them. Four maxims of cooperative principle have been mentioned by Grice [1], including the maxim of quality, the maxim of quantity, the maxim of relevance and the maxim of manner. In the courtroom interaction, a maxim is flouted by the different participants is in the hope of the hearer understanding the implied meaning, that is, conversational implicature. Just as Grice stated that "conversational implicaure is the utterance conveyed the implied meaning during the communication". Just as Mey(2001) has mentioned that "in daily communication, we try to convey propositions that are implicit in our utterances but are merely implied them. Sometimes we are able to draw such inferences only by referring what has been explicitly said to some conversational principle". [2]

Implicature can be considered as the utterance conveyed the implied meaning. Just as Grice has mentioned that "it is a kind of utterance that implied in the conversation or can be regarded as something embedded in the communication". Hu Ying has stated that the utterance is implicit in the language use." Therefore, in the process of understanding, the common knowledge and the inference ability of both the speaker and the hearer are playing the important part. Therefore, implicature is not the meaning referring to the semantic inference, but the inference based on the content of what has been said and the assumptions in order to serve the communication. In order to convey the real purpose and intention, the speaker should violate the maxims so that the hearer can understand the meaning from the utterance and inference of the speaker. It can be called conversation implicature. 


\section{Analysis of Violations of Co-operative Principle in Courtroom Discourse}

During the process of courtroom communication, different participants will employ the different language strategies in order to realize his/her purpose. Different participants will violate these maxims in order to make the listener infer the implied meaning with the help of the corresponding maxims of the cooperative principle. Apart from this, conversational implicature is to aim to arrange and describe the application and comprehension of the speech in the context as a theory about the language use.

\section{Violation of Quantity Maxim}

Eg 1:

Lawyer: Did you marry your wife in 1882 ?

Defendant: Unfortunately for me, I did.

Lawyer: Unfortunately for her, too. [3]

From the above-mentioned case, it is obviously that the answer of the defendant is a sort of breaking the Maxim of Quantity. "Unfortunately for me," it can give us the hint that their marriage is a mistake or they can't live the happy life. Here are two reasons why the defendant provide the over informative response. The response can include more reasons, motivations and causes with different purposes. On the one hand, the relevant information that the defendant provides is only to verify his innocent; on the other hand, it is the way to affect the effect of interaction. In the following inquiry questions, the counsel mentioned that "unfortunately for her", "divorce", "four years later". From all these words, the counsel conveys the information that the real victim of this marriage is not the defendant himself, but his wife.

Eg 2:

Lawyer: The problem in your family exists a long time.

Defendant: Yes, the problem is my father.

Lawyer: Why?

Defendant: I was not raised by my father, but by mother.

Lawyer: Can you tell us the reasons?

Defendant: My father is a kind of irresponsible person. He is selfish and ill-tempered person. I really want to kill him.

The defendant violates the maxim of quantity and gives more information than was required and covey the implicature is that his father is a kind of irresponsible person, he doesn't love his family, his wife and his children. In addition to, the defendant wants to present his view that his life is the lack of love and care. All of these reasons make him lead to this criminal deeds. He wishes that all the judges and the jury could take this testimony into consideration.

Violation of the maxims of quality. Violating of the maxims of quality is the common phenomenon in the courtroom interaction. Participants should observe the quality of maxims: Try to make your contribution on that is true, specially: (i) Do not say what you believe to be false; (ii) Do not say that for which you lack adequate evidence. Therefore, in the courtroom discourse, the maxim of quality refers to the authenticity of the evidence, which is based on the real facts. It is a stringent legal rule for witness to give factual and relevant evidence, not perjury, on the strict legal provisions in court.

Eg 3:

Witness: Everyone, you should believe me, I am not a liar, I have been married with the "the truth" when I was young.

Lawyer: Maybe you are right, but the problem is how long your widower hood is? [4]

From this case, it is evident that the person can't be married with truth. The witness's intention is to convince the audiences that she tells the truth by using hyperbole in here. The lawyer makes full 
use of mistake to rebut him. "But the problem is how long your widower hood is". The lawyer wants to convey the implicauture is that you are a liar, all you mentioned in the court is a lie. The lawyer uses the indirect way and humor language to verify that the words the defendant mentioned are not real.

Violation the maxim of relevance. The maxim of relevance Grice proposed is quite simply, named that it is to make sure that whatever is said is relevant to the topic under discussion. From the cognitive linguistics, relevance can be defined as the bridging between an utterance and the speaker's meaning which depends on the process of cognition and understanding. Succeed communication refers to that the speakers should provide some useful evidence and the hearer can infer his intention, both of two parities can manifested with each other, and the cognitive context should be manifested. Therefore, two important factors should be taken into account, that is, contextual effect and processing effect [5].

Violation the maxim of manner. The principle of manner requires the speaker requires the speaker to say something to the listener in not an obscure, ambiguous, but brief, orderly manner. But in the real interaction, the speaker often says something for different reasons, purposely violating the subordinate maxims of manner which is not understood by the other present persons, so that the conversational implicature which cannot be conveyed to the third person is inferred. However, in the courtroom discourse, despite the fact that the participants are demanded to speak more clearly and directly. Sometimes they will purposely flout the maxim of manner. No matter how the witness avoids speaking the relevant information of the case, the lawyer will ask the question for several times in order to guarantee that he has no doubt about it.

Eg 4:

Lawyer: Mary, would you please to tell us your marriage?

Defendant: Unhappy.

Lawyer: To be more specific. What about, David?

Defendant: hot-tempered, rude manner and a lot of things I don't know.

In this case, it seems that the lawyer wants to know more about the defendant's marriage. Only in this way can make the judge and the jury understand the defendant's unfortunate life and unhappy marriage. In the end, the defendant uses the vague word "a lot of things I don't know", it is the way that the defendant violates the maxim of manners. It is the best way for the defendant to use the vague language to convey the implied meaning that his husband is a bad man and does a lot of bad things. In this case, intention is very important to accomplish the communicative function.

\section{Conclusion}

During the process of courtroom interaction, different participants have different purposes. In order to realize his/her purpose, the lawyer will employ the different language strategy to verify the creditability of the testimony. While for the defendant, he/she will adopt different language to prove his innocent and the real testimony that he/she provided.

\section{Acknowledgement}

This research was financially supported by Technology Department of Henan Province in 2012 (Grant NO. 132400410700) and key planning projects of philosophy and social science of Luoyang in 2014(Grant NO. 2014A028). 


\section{References}

[1]H.P.Grice. Logic and Conversation. In Cole, P and J.L.Morgan(eds.)Syntax and Semantics. Vol.3: Speech Acts. New York: Academic Press, 1975.

[2] L.May.To Grice or not to Grice. Journal of Pragamtics.Vol.12 (2002).No.3, p201-202.

[3] R.Du Cann. The art of the advocate. Harmondsworth: Harmondsworth: Penguin, 1964.

[4]F.L.Wellman. The Art of Cross-examination. XinHua Publishing Press, 2002.

[5] Y.Z.Ma. Analysis of Conversational Implicature of Courtroom English Discourse. (MS. GuangXi University, China 2004).p21-35.

[6] Gazdar,G. Pragmatics: Implicature, presupposition and Logical Form. New York: Academic Press, 1979.

[7]G.John. Language and the Law. London: Longman, 1994.

[8]D.Sperber. and D.Wilson. Relevance: Communication and Cognition. Oxford: Blackwell, 1995.

[9]Q.T.Yuan. The Realization of Lawyer's Language Power in Cross-examination a Pragmatic Approach. (MS. Southwest University of Political Science \& Law, China, 2012).p28-45.

[10] P.Liu. On Pragmatic Presupposition Based on Courtroom Interactions.(MS. Northwest Normal University, China, 2011).p6-10. 